\title{
A comparative study of antepartum and postpartum eclampsia at a tertiary care centre
}

\author{
Shobha Bembalgi, Vishal Kamate*, Samskruti Shetty
}

Department of Obstetrics and Gynaecology, Karnataka Institute of Medical Sciences, Hubli, Karnataka, India

Received: 17 May 2016

Revised: 20 May 2016

Accepted: 23 May 2016

*Correspondence:

Dr. Vishal Kamate,

E-mail: vkamate@gmail.com

Copyright: ( $\odot$ the author(s), publisher and licensee Medip Academy. This is an open-access article distributed under the terms of the Creative Commons Attribution Non-Commercial License, which permits unrestricted non-commercial use, distribution, and reproduction in any medium, provided the original work is properly cited.

\begin{abstract}
Background: Hypertensive disorders complicate 5 to 10 percent of all pregnancies. Eclampsia is one of the dreaded complications of preeclampsia and remains one of the leading causes of maternal deaths in our country. The incidence of post-partum eclampsia is on the rise. Our aim was to study the incidence, demographical factors, and clinical profile associated complications, perinatal and maternal outcomes in pregnancies complicated with antepartum and postpartum eclampsia and compare between the two groups.

Methods: A prospective study was done of all pregnancies complicated with antepartum and postpartum eclampsia over a 10 month period from January 2014 to October 2014 managed at Karnataka institute of medical sciences, Hubli. The results were tabulated and analyzed.

Results: Incidence of antepartum eclampsia was $1.19 \%$ and postpartum eclampsia $0.31 \%$ amongst the patients delivered in Karnataka institute of medical science, Hubli. Average age of the patients was 24.1 years in the antepartum group and $22.7 \mathrm{yrs}$ in postpartum group. Both antepartum and postpartum eclampsia was most commonly seen in primi gravidas. Though both the types of eclampsias were most commonly seen in term patients, preterm patients had a higher incidence of postpartum eclampsia. Majority of the patients of antepartum eclampsia had mild hypertension whereas postpartum eclampsia patients had mostly severe hypertension. Headache was the most common prodormal symptom in both groups. Neonatal mortality was higher in the postpartum group (44\%), whereas maternal mortality was higher in the antepartum group (16.1\%).

Conclusions: Incidence of eclampsia cases is high in tertiary care centres. Eclampsia is still one of the leading causes of maternal deaths in our country. Maternal and periantal mortality is high in both antepartum and postpartum eclampsia cases. The incidence of postpartum eclampsia is significant. Patients with preeclampsia and eclampsia should be closely monitored post natally and measures should be taken to prevent postpartum eclampsias.
\end{abstract}

Keywords: Ante partum eclampsia, Postpartum eclampsia, Preeclampsia, Maternal mortality, Perinatal mortality

\section{INTRODUCTION}

Hypertensive disorders complicate 5 to 10 percent of all pregnancies. ${ }^{1}$ Eclampsia is defined as the presence of seizures in a patient with preeclampsia, not attributable to other causes. ${ }^{2} 16$ percent of maternal deaths are due to hypertensive disorders with eclampsia contributing significantly to these figures especially in the developing countries. ${ }^{3}$ Though many theories have been proposed to explain the pathogenesis of eclampsia, none have been proven conclusively. ${ }^{4}$ In India incidence of eclampsia is reported to be 0.32 to $2.2 \%$ of all deliveries. ${ }^{5-8}$ Eclamptic seizures can occur antepartum, intrapartum or postpartum. Postpartum eclampsia is not as rare a condition as once thought. ${ }^{9}$ Postpartum eclampsia can be subdivided into early postpartum eclampsia occurring within 48 hours and late postpartum eclampsia occurring after 48 hours. $10-25 \%$ of postpartum eclamptic seizures have been reported to be late postpartum. 


\section{METHODS}

We conducted a prospective study of all pregnancies complicated with antepartum and postpartum eclampsia over a 10 month period from January 2014 to October 2014 managed at Karnataka institute of medical sciences, Hubli. The cases were divided into two groups. Group 1 comprised of patients who had only antepartum eclampsia. Group 2 consisted of patients admitted with postpartum eclampsias and those that were admitted in the antenatal period and developed postpartum eclampsia during the course of hospital stay. Data was collected regarding age, parity, period of gestation, B.P at admission, clinical features, prodormal symptoms, mode of delivery, complications, fetal birth weights, fetal outcome and maternal outcome. The results were tabulated and analyzed.

\section{RESULTS}

During the study period a total of 8257 patients delivered at Karnataka institute of medical sciences, Hubli. Of these 99 patients were diagnosed with antepartum eclampsia and 26 with postpartum eclampsia. The incidence of antepartum eclampsia was $1.19 \%$ of all deliveries and postpartum eclampsia was $0.31 \%$. Only 5 out of 99 patients of antepartum eclampsia and 3 out of 26 patients with postpartum eclampsia had taken regular ANC. 6 patients in the first group and 3 in second group had not taken any ANC. Of the total 125 cases, 113 cases were referred from peripheral hospitals.

The youngest patients among these were 19 yrs $(n=2)$ and the oldest was 37 years with mean age of the patients being 24.1 yrs in the antepartum group and 22.7 yrs in the postpartum group.
Distribution of patients as regards to age, parity, period of gestation, B.P at admission, prodormal symptoms, mode of delivery, fetal birth weight, fetal outcome is as shown in the tables.

Table 1: Age distribution.

\begin{tabular}{|lll|}
\hline Age & Antepartum & Postpartum \\
\hline 20 yrs or less & $6(6 \%)$ & $12(46 \%)$ \\
\hline $21-25$ & $48(48.4 \%)$ & $7(27 \%)$ \\
\hline $26-30$ & $43(43.4 \%)$ & $6(23 \%)$ \\
\hline $31-35$ & $1(1 \%)$ & 0 \\
\hline 36 or more & $1(1 \%)$ & 0 \\
\hline
\end{tabular}

Majority of the patients were primigravidas in both the groups and of term gestation.

Table 2: Parity.

\begin{tabular}{|lll|}
\hline Gravida & Antepartum & Postpartum \\
\hline Primi & $58(58.5 \%)$ & $22(84.6 \%)$ \\
\hline G2 & $39(39.4 \%)$ & $3(11.5 \%)$ \\
\hline G3 & $2(2 \%)$ & 0 \\
\hline G4 & 0 & $1(3.8 \%)$ \\
\hline
\end{tabular}

Table 3: Period of gestation.

\begin{tabular}{|lll|}
\hline Gestation & Antepartum & Postpartum \\
\hline$<28$ weeks & $1(1 \%)$ & 0 \\
\hline $28-36.6$ weeks & $13(13.1 \%)$ & $10(38.5 \%)$ \\
\hline 37-40 weeks & $78(78.8 \%)$ & $13(50 \%)$ \\
\hline 40.1-42 weeks & $7(7 \%)$ & $2(7.7 \%)$ \\
\hline$>42$ weeks & 0 & $1(3.8 \%)$ \\
\hline
\end{tabular}

Table 4: B.P at admission.

\begin{tabular}{|llllll|}
\hline Systolic BP & APE & PPE & Diastolic BP & APE & PPE \\
\hline $121-139$ & 7 & 4 & $81-89 \mathrm{~mm}$ & 0 & 3 \\
\hline $140-159$ & 57 & 8 & $90-99 \mathrm{~mm}$ & 35 & 4 \\
\hline $160-179$ & 33 & 11 & $100-109 \mathrm{~mm}$ & 42 & 15 \\
\hline 180 and more & 2 & 3 & $110-119$ & 19 & 3 \\
\hline
\end{tabular}

Majority of the patients of antepartum eclampsia had mild hypertension whereas postpartum eclampsia patients had mostly severe hypertension.

Most patients in both groups experienced headache before the onset of seizures. Visual disturbances were next most common symptoms. Some patients experienced both these symptoms.

Table 5: Prodormal symptoms.

\begin{tabular}{|lll|}
\hline Prodormal symptoms & Antepartum & Postpartum \\
\hline Headache & $85(85.6 \%)$ & $15(57.7 \%)$ \\
\hline Visual disturbance & $10(10.1 \%)$ & $4(15.3 \%)$ \\
\hline Epigastric pain & $2(2 \%)$ & $1(3.8 \%)$ \\
\hline Dyspnoea & 0 & $1(3.8 \%)$ \\
\hline None & $5(5 \%)$ & $11(42.3 \%)$ \\
\hline
\end{tabular}

Majority patients delivered vaginally in both groups. 


\begin{tabular}{|lll|}
\hline Delivery & Antepartum & Postpartum \\
\hline Vaginal & $71(71.7 \%)$ & $15(57.7 \%)$ \\
\hline Cesarean & $28(28.2 \%)$ & $11(42.3 \%)$ \\
\hline
\end{tabular}

Table 7: Fetal birth weight.

\begin{tabular}{|lll|}
\hline Birth weight & Antepartum & Postpartum \\
\hline$<1500$ gms & $2(2 \%)$ & $5(19.2 \%)$ \\
\hline $1500-2000$ gms & $10(10.1 \%)$ & $12(46.1 \%)$ \\
\hline $2001-2500$ gms & $20(20.2 \%)$ & $13(50 \%)$ \\
\hline $2501-3000$ gms & $54(54.5 \%)$ & $5(19.2 \%)$ \\
\hline $3001-3500$ gms & $13(13.1 \%)$ & $1(3.8 \%)$ \\
\hline$>3501$ gms & 0 & 0 \\
\hline
\end{tabular}

Table 8: Fetal outcome.

\begin{tabular}{|lll|}
\hline Fetal outcome & Antepartum & Postpartum \\
\hline Live births & $93(93.9 \%)$ & $17(65.3 \%)$ \\
\hline Still births & $6(6 \%)$ & $9(34.6 \%)$ \\
\hline Neonatal deaths & $10(10.1 \%)$ & $7(26.9 \%)$ \\
\hline
\end{tabular}

Fetal outcome was worse in post-partum eclampsia cases but then more babies delivered by this group of patients were low birth weight babies and preterm.

Thrombocytopenia was seen in 21 cases in group 1 and 6 cases in group 2.

Altered coagulation profile was seen in 11 cases in group 1 and 5 cases in group 2.

4 patients in group 1 developed pulmonary edema. There were total of 65 maternal deaths during the study period. Of these $19(29.2 \%)$ deaths were seen in eclampsia patients. There were $16(16.1 \%)$ deaths in the antepartum group and $3(11.5 \%)$ in the postpartum group. Karnataka institute of medical sciences, Hubli being a tertiary care centre with a wide referral area and many complicated cases are referred here accounting for a higher maternal mortality rate.

\section{DISCUSSION}

It is estimated that current incidence of eclampsia is 5\%$8 \%$ amongst women developing pre-eclampsia in the developing countries. Though the incidence of eclampsia in India has been reported to be 0.7 to $2.2 \%$ by various authors and this is comparable to our study, it cannot be generalized to the entire population as most studies are reported from tertiary care and referral centres. ${ }^{5-8}$ Antepartum eclampsia is associated with high maternal morbidity and mortality and is an indication for immediate termination of pregnancy. ${ }^{10,11}$ Use of magnesium sulphate reduces the mortality rates in eclampsia. ${ }^{12}$ Leitch and colleagues showed that over a 60 year period the incidence of eclampsia had fallen from
$74 / 10000$ to $7.4 / 10000 .^{9}$ This can be attributed to widespread increase in antenatal care and use of prophylactic magnesium sulphate regimens. ${ }^{13}$ The incidence of postpartum eclampsia has however increased and postpartum eclampsia is not as rare a condition as was once thought. ${ }^{9}$ Watson et al reviewed 132 cases of eclampsia and found that $37(27 \%)$ occurred in the postpartum period. ${ }^{14}$ Of these $17(47 \%)$ occurred at least 48 hours postpartum. In our study postpartum eclampsias accounted for $20.8 \%$ of all eclampsia cases which is comparable to other Indian studies by Parneet Kaur (20\%) Sunitha TH (18\%) et al. ${ }^{6,15}$

Most patients in our study who developed antepartum eclampsia were from 21-25 years age group which is comparable to the study by Neelam Rajput et al. ${ }^{16}$ and Pradeep MR et al who have presented a similar type of study from south Karnataka region. ${ }^{17}$ However most of our postpartum eclampsia patients were from a younger age group, $46 \%$ being 20 years or less comparable to the age distribution reported by Choudhary et al. ${ }^{18}$

Majority of our patients from both groups were primigravidas which is true for all other studies reported from the Indian subcontinent. ${ }^{6,15,18,19}$ In both the groups majority patients were 37-40 weeks gestation which is comparable to studies by Malay Sarakar, Sunitha TH et al. ${ }^{6,20}$ However the incidence of preterm patients was much higher in the postpartum group compared to antepartum group.

\section{ACKNOWLEDGEMENTS}

We are thankful the Head of the Department for guiding us through the study. We are also thankful to all the post graduate students for helping to collect the data.

Funding: No funding sources

Conflict of interest: None declared

Ethical approval: The study was approved by the Institutional Ethics Committee

\section{REFERENCES}

1. Nadkarni J, Bahl J, Parekh P. Perinatal Outcome in Pregnancy Associated Hypertension. Indian Pediatrics. 2001;38:174-8.

2. Anne BW, Audrey FS, Jason H, Hani KA. Secular trends in the rates of preeclampsia, eclampsia, and gestational hypertension, United States, 1987-2004. Am J Hypertens. 2008:21(5):521-6.

3. Duley L. Maternal mortality associated with hypertensive disorders of pregnancy in Africa, Asia, Latin America and the Caribbean. $\mathrm{Br} \mathrm{J}$ Obstet Gynecol. 2005;99:547-53.

4. Sibai BM. Diagnosis, prevention and management of eclampsia. Obstetr Gynecol. 2005;105(2):402-10.

5. Deepika P, Banashree D, Paramita H, Shilpa. Maternal and perinatal outcome in eclampsia and factors affecting the outcome: a study in North 
Indian population. Int J Reprod Contracept Obstet Gynecol. 2014;3(2):347-51.

6. Sunita TH, Rathnamala MD. Eclampsia in a teaching hospital: incidence, clinical profile and response to magnesium sulphate by Zuspan's regimen. IOSR J Dent Med Sci. 2013;4(2):01-5.

7. Swain S, Ojha KN. Maternal and Perinatal mortality due to eclampsia. Indian Pediatr. 1993;30:771-3.

8. Rajasri GY, Jaju PB, Vanishree M. Eclampsia and perinatal outcome: a retrospective study in a teaching hospital. J Clin Diagn Res. 2011;5(5):1056-9.

9. Leitch CR, Cameron AD, Walker JJ. The changing pattern of eclampsia over a 60-year period. Br J Obstet Gynaecol. 1997;104:917-22.

10. WHO recommendations for prevention and treatment of pre-eclampsia and eclampsia. 2011. Available at http://apps.who.int/iris/bitstream/10665/44703/1/978 9241548335_eng.pdf. Accessed on 25 April 2016.

11. Tranquilli AL, Dekker G, Magee L, Roberts J, Sibai BM, Steyn W, et al. The classification, diagnosis and management of the hypertensive disorders of pregnancy: a revised statement from the ISSHP. Pregnancy Hypertens. 2014;4:97-104.

12. Sawhney H, Aggarwal N, Biswas R, Vasishta K, Gopalan S. Maternal mortality associated with eclampsia and severe preeclampsia of pregnancy. J Obstet Gynaecol Res. 2000;26(5):351-6.

13. Jennifer AH, Sarka L, Joseph KS. Epidemiology of pre-eclampsia and the other hypertensive disorders of pregnancy. Best Pract Res Clin Obstet Gynaecol 2011;25:391-403.
14. Watson DM, Sibai BM, Shaver DC, Dacus JV, Anderson GD. Late postpartum eclampsia. An update. Southern Med J. 1983;76:(12):1487-9.

15. Kaur P. A clinical study of eclampsia in a referral hospital. J South Asian Feder Obster Gynaecol. 2012;4(2):113-5.

16. Neelam R, Yogendra SV, Geeta A. Comparative study of eclamptic and non-eclamptic convulsive disorders in pregnancy. Sch J App Med Sci. 2014;(5A):1559-64.

17. Pradeep MR, Lalitha S. retrospective study of eclampsia in a teaching hospital. Intern $\mathrm{J}$ Recent Trends Sci Tech. 2013;8(3):171-3.

18. Choudhary P. Eclampsia: a hospital based retrospective study. Kathmandu Uni Med J. 2003;1(4):237-41.

19. Anuja B, Sayali K, Sunita G, Anjali K, Sulabha J, Savita S. Eclampsia: maternal and fetal outcome. J South Asian Feder Obster Gynaecol. 2013;5(1):1921.

20. Malay S, Sanjay B, Sajal KM, Sandhya D, Dibyendu R, Jaydeb M, et al. Maternal mortality associated with eclampsia in an Indian Medical College: a four year retrospective study. J Med Medic Sci. 2013;4(10):394-8.

21. Savita RS, Deepika, Anshu, Smiti N. Maternal and perinatal outcome in severe preeclampsia and eclampsia. J South Asian Feder Obster Gynaecol. 2009;1(3):25-8.

22. Aagaard-Tillery KM, Belfort MA. Eclampsia morbidity, mortality and management. Clin Obstetr Gynecol. 2005;48:12-20.

Cite this article as: Bembalgi $\mathrm{S}$, Kamate V, Shetty $\mathrm{S}$. A comparative study of antepartum and postpartum eclampsia at a tertiary care centre. Int $\mathbf{J}$ Reprod Contracept Obstet Gynecol 2016;5:1728-31. 